University of Nebraska - Lincoln

DigitalCommons@University of Nebraska - Lincoln

Distribution and Abundance of the Mariana Subspecies of the Common Moorhen

\author{
Leilani L. Takano \\ Oregon State University \\ Susan M. Haig \\ U.S.G.S., Susan_Haig@usgs.gov
}

Follow this and additional works at: https://digitalcommons.unl.edu/usgsstaffpub

Takano, Leilani L. and Haig, Susan M., "Distribution and Abundance of the Mariana Subspecies of the Common Moorhen" (2004). USGS Staff -- Published Research. 693.

https://digitalcommons.unl.edu/usgsstaffpub/693

This Article is brought to you for free and open access by the US Geological Survey at DigitalCommons@University of Nebraska - Lincoln. It has been accepted for inclusion in USGS Staff -- Published Research by an authorized administrator of DigitalCommons@University of Nebraska - Lincoln. 


\title{
Distribution and Abundance of the Mariana Subspecies of the Common Moorhen
}

\author{
LEILANI L. TAKANO ${ }^{1,2}$ AND SUSAN M. HAIG ${ }^{2}$ \\ ${ }^{1}$ Department of Fisheries and Wildlife, Oregon State University, Corvallis, OR 97331, USA
}

${ }^{2}$ USGS Forest and Rangeland Ecosystem Science Center, 3200 SW Jefferson Way, Corvallis, OR 97331, USA

\begin{abstract}
Island-wide surveys for the endangered Mariana subspecies of the Common Moorhen ( Gallinula chloropus guami) were conducted on Guam and the Commonwealth of the Northern Mariana Islands from May through September 2001. Based on these counts, the total adult moorhen population is estimated to be 287, with 154, 41, 2, and 90 adult moorhens on Saipan, Tinian, Rota, and Guam, respectively. Results suggest an overall increase in birds on Saipan and Tinian, although moorhen numbers on Guam may be declining. High counts of moorhens on Lake Hagoi, Tinian, during the wet season suggested movement from Saipan to Tinian occurs at the onset of the wet season each year. Conservation efforts need to consider Saipan and Tinian moorhens as a single demographic unit. Further, monitoring of moorhens, invasive vegetation management, and predator and ungulate control on wetlands are critical for this small population. Received 15 September 2003, accepted 20 January 2004.

Key words.-Abundance, distribution, Gallinula chloropus guami, Guam, Mariana Islands, Mariana Common Moorhen, movement, predation, wetlands.
\end{abstract}

Waterbirds 27(2): 245-250, 2004

The Mariana subspecies of the Common Moorhen (Gallinula chloropus guami) is listed as endangered by U.S. Fish and Wildlife Service (USFWS 1984) and is one of the last remaining endemic wetland-dependent birds in the Mariana Islands. One of twelve subspecies of the globally-distributed Common Moorhen (Gallinula chloropus), it has a population estimated to be less than 400 birds (Stinson et al. 1991; Clements 2000; Bannor and Kiviat 2002). A non-migratory resident of the Mariana archipelago, the Mariana Common Moorhen resembles the Eurasian subspecies (chloropus and orientalis) in having a frontal shield with a rounded top, which is typically found in moorhens of Old World origin, but differ slightly in coloration and size (Baker 1951). It differs from the Hawaiian moorhen subspecies (sandvicensis), which has a larger truncated frontal shield and is most likely of New World origin (Hartert 1898; Baker 1951; Ripley 1977). The Mariana Common Moorhen was first recorded in the Mariana Islands on Guam by Quoy and Gaimard (1824-1826) and archaeological excavations revealed the presence of moorhens on Rota, Mariana Islands between 1,500-2,000 years ago (Butler 1988).

Historically, Mariana Common Moorhens were considered numerous and widely distributed across taro patches, rice paddies, and fresh and brackish wetlands (Stott 1947; Marshall 1949; Baker 1951). However, major wetland loss has occurred in the Marianas due to changing agricultural practices, encroachment by undesirable vegetation, and clearing and filling of wetlands for development. On Pagan, moorhens were extirpated by large quantities of ash and cinder deposited from a volcanic eruption in May 1981 and the destruction of vegetation by feral ungulates (Stinson et al. 1991; USFWS 1992). Moorhens are year-round breeders and use freshwater wetland areas on Saipan, Tinian, Rota, and Guam. Only these islands contain wetlands capable of supporting moorhens in the Mariana archipelago.

There has not been a recent nor complete survey of the Mariana Common Moorhen. However, the Mariana Common Moorhen uses easily identifiable and discrete wetlands and we surveyed the islands at various temporal and spatial scales to determine a current population size and also seasonal distribution as wetland use by moorhens varies during dry and wet phases of the annual cycle.

\section{STUDY AREA}

The Mariana archipelago is located approximately $1,500 \mathrm{~km}$ east of the Philippine Islands and includes 15 islands that extend $750 \mathrm{~km}$ between $13^{\circ} 14^{\prime} \mathrm{N}, 144^{\circ} 45^{\prime} \mathrm{W}$ and $20^{\circ} 3^{\prime} \mathrm{N}, 144^{\circ} 54^{\prime} \mathrm{W}$ (Fig. 1). The largest and south- 
ern-most island is the U.S. Territory of Guam; the other 14 islands consist of the U.S. Commonwealth of the Northern Mariana Islands (CNMI). Though volcanic in origin, the islands where moorhens currently occur, Saipan, Tinian, Rota, and Guam, are mainly forested limestone plateaus.

Climate in the Marianas is tropical, with an average annual temperature of $26^{\circ} \mathrm{C}$ and annual precipitation ranges from 2,000-2,600 $\mathrm{mm}$ (Kendrick 1997). The year is divided into the dry and wet season. Generally, the dry season falls between January-May and wet season from July-November. Other months are transitional periods that may be dry or wet, depending on the particular year. On average, about $15 \%$ of annual rainfall occurs during the dry season.

\section{METHODS}

Moorhen adults were surveyed on wetlands across Saipan, Tinian, Rota, and Guam. We reviewed literature on past moorhen surveys and descriptions of wetlands in the Marianas to identify wetlands appropriate for surveys (Stinson et al. 1991; USFWS 1992; Wiles and Ritter 1993; USFWS 1996; Ritter 1997; Worthington 1998). Survey efforts covered all permanent and seasonal wetlands on Saipan and Tinian during the dry and wet seasons (from 16 May through 6 September 2001), on a golf course on Rota during the wet season (13 August 2001). On Guam, all permanent wetlands were surveyed where access was possible (approximately 90\% of all wetlands on Guam) during the dry season (May and June 2001). With the exception of Rota, each islandwide survey was carried out over a two-week period.

Three approaches were used to survey for moorhens: 1) visual observations; 2) visual observations accompanied with audio playbacks; and 3) flushing birds out of vegetation. Most surveys consisted of visual observations by two persons using binoculars during crepuscular hours, when moorhens were most active (Craig 1979; L. Takano, pers. obs.). Depending on the size of the wetland, 15 minutes to three hours was spent at each site.

- Uracas

- Maug

- Asuncion

Agrihan

Pagan 0

Alamagan .

Guguan .

Pacific Ocean

Sarigan

Anatahan

- Farallon de Medinilla
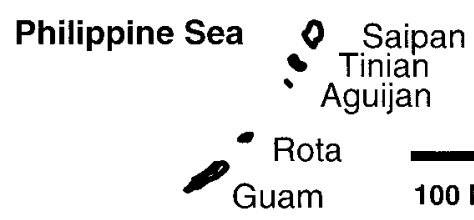

100 kilometers

Figure 1. Location of Guam and the Commonwealth of the Northern Mariana Islands, U.S.A.
Visual observations and audio playbacks were used in wetlands that were heavily vegetated. During these surveys, observers were stationed in different areas of the wetland and hidden from view within the vegetation. We found that staying hidden was crucial in order for moorhens to respond to audio playbacks. During audio surveys, we spent 15 minutes at each site and adult moorhen calls were played three to five times at approximately 30-second bursts. Playback calls have been used successfully by Brackney and Bookout (1982) to survey the Common Moorhen on Lake Erie in Ohio. They found isolated moorhen pairs responded to the tape-recorded calls as readily as pairs in high-density areas and responded equally well throughout the breeding season. However, males responded (93\%) to tape calls much more frequently than females $(21 \%)$. Therefore, we believe the survey method of using audio playbacks cause underestimations. In addition, survey efforts included a complete census of all individuals in man-made wetlands such as small drainage basins, golf-course ponds, and fish ponds, where the perimeter of the wetland was walked and moorhens flushed out of narrow bands of vegetation.

The total count of moorhen adults was summed across all wetlands visited to determine moorhen numbers for each island. Sex and age (adult and subadult) classes were not differentiated. The sexes are monomorphic, except for size (average of $340 \mathrm{~g}$ and $265 \mathrm{~g}$ for males and females, respectively) which was difficult to judge in the field (Dunning 1993). Further, a subadult stage occurs during the moorhen's first 14-21 weeks of life and is characterized by a duller plumage and smaller frontal shield than adults, but can be difficult to identify (Ritter 1994). Thus, subadults were included in our adult moorhen counts.

\section{RESULTS}

\section{Saipan and Tinian}

The total number of adult moorhens on Saipan and Tinian was 154 and 41, respectively, based on the maximum number of adults counted on Saipan and Tinian wetlands during any one survey period. The average number of adult moorhens in each two-week period on Saipan and Tinian was $122(\mathrm{SD} \pm$ 23.7), and 36 (SD \pm 7.26), respectively. Moorhens were present on seven seasonal and 34 permanent wetlands (Table 1), and on $73 \%(41 / 56)$ of all wetlands surveyed. As the wet season progressed, the numbers decreased on Saipan permanent wetlands, while they increased on Saipan seasonal wetlands and on Tinian's semi-permanent wetland, Lake Hagoi (Fig. 2). Chalan Kanoa (CK) potholes on Saipan became important sites in the wet season, as areas of open water increased, augmenting moorhen habitat. The total numbers of adult moorhens increased on this wetland complex as the wet season progressed. 
Table 1. Number of adult moorhens present on seasonal and permanent Saipan wetlands during August 2001. These data were used to estimate 154 adult moorhens on Saipan.

\begin{tabular}{lcc}
\hline \hline Site & No. of adults & Type \\
\hline Agriculture Station Ponds & 2 & permanent \\
Annie's Pond & 6 & permanent \\
Black Microl Ponds & 2 & permanent \\
Chalan Kanoa Potholes 1-9 & 49 & permanent \\
Dan Dan Range & 3 & permanent \\
Department of land and Natural Resources Ditch & 1 & permanent \\
Education Drainage & 1 & seasonal \\
Falig Pond & 8 & permanent \\
Flores Pond & 8 & seasonal \\
Handsome Pond & seasonal \\
Kagman North & 4 & permanent \\
Kingfisher Golf Course Ponds & 2 & permanent \\
Lake Susupe & 7 & permanent \\
Lao Lao Bay Golf Course Ponds & 1 & permanent \\
Mariana Country Club Ponds & 6 & permanent \\
Oleai Potholes 1-5 & 4 & permanent \\
Price Costco Wetland & 8 & permanent \\
Tank & 32 & permanent \\
\hline
\end{tabular}

Rota

No moorhens were detected on wetlands at the Rota golf course.
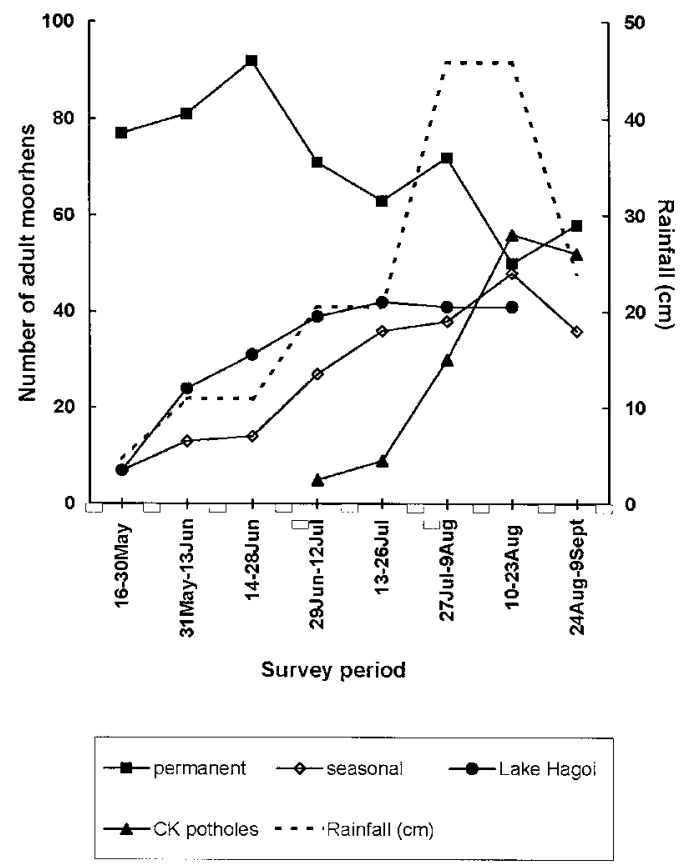

Figure 2. Saipan and Tinian adult moorhen surveys conducted from 16 May through 6 September 2001 and Saipan 2001 rainfall levels. Surveys included Tinian's Lake Hagoi and Saipan's Chalan Kanoa (CK) potholes, as well as other permanent and seasonal wetlands on the island.

\section{Guam}

On Guam, 90 moorhens were present at one seasonal and 21 permanent wetlands, and were present in $79 \%(22 / 28)$ of all wetlands surveyed (Table 2). Adult moorhen numbers averaged 88.5 ( $\mathrm{SD} \pm 2.12)$. Five sites were inaccessible because surrounding vegetation was overgrown and the area of open water was minimal. However, we believe these areas were little used by moorhens during the dry season (i.e., Camp Covington $\mathrm{Na}$ val Station Marsh, Sasa Bay wetland and NavMag Ponds).

\section{Moorhen Population Estimate}

Based on surveys, the total adult moorhen population is estimated to be 287 , with 154 , 41, 2, and 90 adult moorhens on Saipan, Tinian, Rota, and Guam, respectively.

\section{DISCUSSION}

\section{Saipan and Tinian}

Compared to past surveys, the moorhen counts on Saipan and Tinian resulted in higher numbers on Saipan, but fewer birds on Tinian. Past moorhen surveys estimated 100 and 75 birds on Saipan and Tinian, re- 
Table 2. Number of adult moorhens present on seasonal and permanent Guam wetlands in May 2001. These data were used to estimate 90 adult moorhens on Guam.

\begin{tabular}{lcc}
\hline \hline Site & No. of adults & Type \\
\hline Agana Swamp & 4 & permanent \\
Fena Dam (behind spillway) & 2 & permanent \\
Fena Valley Reservoir & 33 & permanent \\
Leo Palace Golf Course Ponds & 10 & permanent \\
Masso Reservoir & 2 & permanent \\
Naval Magazine Pond & 3 & permanent \\
Prison Ponding Basin & 2 & seasonal \\
San Luis Ponds & 3 & permanent \\
Shell Inc. Wetland & 2 & permanent \\
Shell Inc. drainage basin & 4 & permanent \\
Toguan Bay Treatment Ponds & 9 & permanent \\
Talafofo Fish Ponds & 6 & permanent \\
Talafofo Golf Course Ponds & 10 & permanent \\
\hline
\end{tabular}

spectively (Stinson et al. 1991), and a more recent estimate of 50 birds on Tinian (USFWS 1996). These surveys were conducted throughout the dry and wet seasons and were the highest number detected during any visit. Stinson et al. (1991) surveys recorded juveniles (although these were a small fraction of the individuals) in estimates and some "guesses" were made regarding the number of moorhens present on wetlands that could not be surveyed (D. Stinson, pers. comm.). Thus, evaluating changes in moorhen numbers on Saipan and Tinian is challenging because our survey was more comprehensive than past survey efforts. Further, by conducting multiple surveys on Saipan and Tinian simultaneously and basing our total adult count on the highest number of adults detected during any one survey period, we minimized counting errors that may occur due to inter-island movement between islands. Thus, we believe our survey methods produced more accurate counts than past surveys.

Results of our surveys and a radio telemetry study (Takano 2003) suggest that moorhens on Saipan and Tinian form a single unit. On Lake Hagoi, Tinian, the greatest number of adult moorhens occurred during the wet season. Only emigration from Saipan, a source population, can explain the increase in numbers because other wetlands on Tinian are not capable of supporting a large number of moorhens (Stinson et al. 1991; USFWS 1992). Furthermore, no juveniles were observed on Lake Hagoi during surveys and active nests were recorded first in late July. Thus, maturation of juveniles into subadults, which takes approximately 5-13 weeks (Ritter 1994), does not explain the increase in adult numbers on Lake Hagoi. Based on low counts of moorhens on Lake Hagoi during the dry season and other survey data (e.g., USFWS 1996), we suggest that moorhen movement to Saipan from Tinian probably occurs at the onset of the dry season.

On Saipan, surveys revealed increased numbers of adult moorhen at seasonal wetlands and the CK potholes and fewer at permanent wetlands as the wet season progressed. Intra-island movement on Saipan increased during the wet season. This movement is likely a response to availability of new food resources and habitat during the wet season. Understanding movement of the Mariana Common Moorhen in the Mariana Islands will help in prioritizing wetland conservation efforts for this endangered subspecies.

\section{Rota}

Our surveys did not detect moorhens on Rota. However, three months after our surveys, two adult moorhens were observed on the golf course's sewage treatment pond during the Christmas Bird Count (CBC). One month after the $\mathrm{CBC}$, one moorhen was observed at a farm, where it lived for several weeks with chickens, bathed in the chickens' water pans, and roosted in a Tangantangan tree (Leucaena sp.) (P. Wenninger, pers. 
comm.). In 1998, Worthington reported at least one breeding and the most recent CBC (2002) reported two adults. Our efforts may have failed to detect moorhens because our search area was restricted to golf course wetlands and they may have been using other areas, such as the farm or ephemeral streams.

\section{Guam}

Our count of 90 adult moorhens on Guam is lower than past estimates of 100-125 birds (GDAWR unpublished data cited in Stinson et al. 1991) and previous estimates may have been conservative. While they did exclude juveniles from counts (M. Ritter, pers. comm.), surveys, which covered five seasonal and 14 permanent wetlands, were conducted during the wet season and may not have covered all available sites. Conversely, our surveys, which covered one seasonal and 27 permanent wetlands, were conducted during the dry season when moorhens were more concentrated on permanent wetlands and easier to count.

Moorhens on Guam may be declining because permanent natural wetland areas have been considerably degraded and reduced throughout past years due to encroachment of the tall reed, Phragmites karka (Ritter 1997; Ritter and Savidge 1999; L. Takano, pers. obs.). Comparison of monthly moorhen surveys, which included Fena Reservoir counts from March through May 1988 (GDAWR 1988) and 2000 revealed a minimum of 28 adults in 2000 and 57 in 1988. These months are generally characterized as the dry season. During the dry season, most of the Guam moorhens reside on Fena Reservoir because wetland habitat is scarce elsewhere. The number of adult moorhens found on newly created golf course wetlands (ten small permanent wetlands were created after 1991) does not account for the difference in adult numbers because most of the golf course wetlands are small and have only one breeding pair on each pond. Furthermore, disturbance of emergent wetland vegetation by Feral Pigs (Sus scrofa) and Water Buffalo (Bubalus bubalis), which are numerous on Guam (Conry 1989, L. Takano, pers. obs.), probably have decreased habitat quality for moorhens (Stinson et al. 1991; Ritter 1997; Takano 2003).

Moorhens appear to be subject to heavy egg and chick loss on Fena Reservoir. Nest counts on six territories revealed $59 \%$ egg and $78 \%$ chick loss (L. Takano, unpubl. data). For other Common Moorhens elsewhere, egg and chick loss is considerably lower. For Hawaiian Moorhens, 21\% egg loss due to predation or human disturbance was reported (Byrd and Zeillemaker 1981). In England, both Wood (1974) and Relton (1972) reported less than $10 \%$ chick loss. Nest flooding combined with the lack of suitable emergent vegetation for nesting habitat has also been suggested to contribute to the rarity of chicks recorded during monthly counts at Fena Reservoir (GDAWR, unpubl. data). However, we strongly suspect that the Brown Treesnake (Boiga irregularis) is a major predator of moorhen eggs and chicks on Guam. Eggs disappeared at night without any shell fragments left behind and two Brown Treesnakes were seen swimming on Fena Reservoir at night.

\section{Conservation Implications and Future Research}

This study represents the most complete survey effort for the Mariana Common Moorhen and is a rare example of a survey that spanned multiple islands (however, see Engilis and Pratt 1993; Reed and Oring 1993). Based on this study and the CBC for Rota, we estimate the total adult population to be 287. However, because of the secretive nature of moorhens and their affinity to hide in vegetation, our estimate may be slightly conservative. Nevertheless, a small population of approximately 300 birds with possibly declining moorhen numbers on Guam is in need of conservation strategies. We recommend conducting annual moorhen surveys during the dry season to assess the population structure and closely monitor the status of the Mariana Common Moorhen, especially on Guam. Because most endemic waterbirds in the Marianas have been extirpated, including White-browed Crake (Porzana cinerea), Guam's Nightingale Reed-warbler ( $A c$ rocephalus luscnia), and Marianas Mallard 
(Anas oustaleti), it is particularly important to closely monitor the remaining native wetland birds such as the endangered Nightingale Reed-warbler (Acrocephalus luscinia luscinia) and Mariana Common Moorhen. It also is important to treat moorhens on Saipan and Tinian as a single demographic unit. Future efforts should focus on improving counts of moorhens in wetlands encroached by Phragmites karka and on management of invasive vegetation and predator and ungulate control methods on wetlands in the Marianas.

\section{ACKNOWLEDGMENTS}

We thank the U.S. Navy for providing support for this study and U.S. Geological Survey, Forest and Rangeland Ecosystem Science Center for providing logistic and technical support. We are especially thankful to Grant Beauprez, Elizabeth Midfelt, and Caleb Spiegel for their dedication and hard work in the field. This study would not have been possible without the cooperation from agencies and private landowners throughout the Marianas. In particular, we would like to thank the following for their assistance and expertise: Tina de Cruz (CNMI Division of Fish and Wildlife) and Robert Wescom (U.S. Navy Environmental Division), as well as Guam Department of Corrections, Kingfisher Golf Resort, Leo Palace Golf Resort, Shell, Inc., and Talafofo Golf Resort for allowing access to wetlands on their property.

\section{LiterATURE CITED}

Baker, R. H. 1951. The avifauna of Micronesia, its origin, evolution, and distribution. University of Kansas Publications of the Museum of Natural History 3: 1-159.

Bannor, B. K. and E. Kiviat. 2002. Common moorhen (Gallinula chloropus). In The Birds of North America, No. 685 (A. Poole and F. Gills, Eds.). The Birds of North America, Inc., Philadelphia.

Brackney, A. W. and T. A. Bookhout. 1982. Population ecology of common gallinules in southwestern Lake Erie marshes. Ohio Journal of Science 82: 229-237.

Butler, B. M. [Ed.]. 1988. Archaeological investigations on the north coast of Rota, Mariana Islands. Micronesian Archaeological Survey Report 23: 1-482. [S. Illinois University at Carbondale, Center for Archaeology Investigations Occ. Paper 8]

Byrd, G. V. and C. F. Zeillemaker. 1981. Ecology of nesting Hawaiian common gallinules at Hanalei, Hawaii. Western Birds 12: 105-116.

Clements, J. F. 2000. Birds of the World: A Check List. Fifth Edition. Ibis Publishing Company, Visa, CA.

Conry, P.J. 1989. Ecology of the wild (feral) pig (Sus scrofa) on Guam. Technical Report No. 7. Division of Aquatic and Wildlife Resources, Department of Agriculture, Mangilao, Guam.

Craig, J. L. 1979. Habitat variation in the Social Organiziation of a communal gallinule, the Pukeko, Porphyrio porphyrio melanotus. Behavioral Ecology and Sociobiology 5: 331-358.

Dunning, J. B. [Ed.]. 1993. CRC Handbook of Avian Body Masses. CRC Press Inc., Boca Raton, FL.
Engilis, E., Jr. and T. K. Pratt. 1993. Status and population trends of Hawaii's native waterbirds. Wilson Bulletin 105: 142-158.

Guam Division of Aquatic and Wildlife Resources (GDAWR). 1988. Unpublished annual report, Department of Agriculture, Mangiloa, Guam.

Hartert, E. 1898. On the birds of the Marianne Islands. Novitates Zoologicae 5: 51-69.

Kendrick, E. [ed.]. 1997. Micronesia Handbook 4th Edition. Moon Publications Inc., Chico, CA.

Marshall, J. T., Jr. 1949. The endemic avifauna of Saipan, Tinian, Guam and Palau. Condor 51: 200-221.

Quoy, J. R. C. and P. J. Gaimard. 1824-26. Voyage autour du monde. Entepes par ordre du Roi. Execute sur les corvettes de S. M.l'Uraine et la Physicienne, pendant les annees 1817, 1818, 1819, et 1829. Par M. Louis de Freycinet, Capitaine de Vaisseau. Paris, Zoologie: 1-712.

Reed, J. M. and L. W. Oring. 1993. Long-term population trends of the endangered ae'o (Hawaiian Stilt, Himantopus mexicanus knudseni). Transactions of the western section of the wildlife society. 29: 54-60.

Relton. J. 1972. Breeding biology of moorhens on Huntingdonshire farm ponds. British Birds 65: 248- 256.

Ripley, D. S. 1977. Rails of the world. M. F. Fehelel Publisher, Toronto, Canada.

Ritter, M. W. 1994. Notes on nesting and growth of Mariana Common Moorhens on Guam. Micronesica 27: 127-132.

Ritter, M. W. 1997. Wetland habitat characteristics and wetland use by Mariana Common Moorhen on Guam. Unpublished M.S. thesis. University of Nebraska, Lincoln.

Ritter, M. W. and J. A. Savidge. 1999. A predictive model of wetland habitat use on Guam by endangered Mariana Common Moorhens. Condor 101: 282-287.

Stinson, D. W., M. W. Ritter, and J. D. Reichel. 1991. The Mariana Common Moorhen: decline of an island endemic. Condor 93: 38-43.

Stott, J., Jr. 1947. Notes on Saipan birds. Auk 64: 532-527.

Takano L. L. 2003. Seasonal movements, home range, and abundance of the Mariana Common Moorhen (Gallinula chloropus guami) on Guam and the Northern Mariana Islands. Unpublished M.S. thesis, Oregon State University, Corvallis. 96 pp.

U.S. Fish and Wildlife Service. 1984. Nine Mariana Islands species listed as Endangered. Endangered Species Technical Bulletin 9(9): 1, 5-6.

U.S. Fish and Wildlife Service. 1992. Recovery plan for the Mariana Common Moorhen, Gallinula chloropus guami. U.S. Fish and Wildlife Service, Portland, OR.

U.S. Fish and Wildlife Service. 1996. Characteristics of Mariana Common Moorhens and wetland habitats within the U.S. Department of Navy's lease area and exclusive military use area on the island of Tinian, Commonwealth of the Northern Mariana Islands, Jul 1994-Aug 1995. Prepared for U.S. Dept. Navy, Pacific Division, Naval Facilities Engineering Command, Honolulu, HI. U.S. Fish and Wildlife Service, Pacific EcoRegion, Ecological Services, Honolulu, HI. 32 pp.

Wiles, J. G. and M. W. Ritter. 1993. Guam. In D. A. Scott [Ed.], A Directory of Wetlands in Oceania: 129-178. IWRB, Slimbridge, U.K. and AWB. Kuala Lumpur, Malaysia.

Wood, N. A. 1974. The breeding behaviour and biology of moorhen. British Birds 67: 104-115, 137-158.

Worthington, D. V. 1998. Inter-island dispersal of the Mariana Common Moorhen: a recolonization by an endangered species. Wilson Bulletin 110: 414-417. 